\title{
ISOLATION AND CHARACTERIZATION OF MICROORGANISMS OF EJAMAH-EBUBU OIL SPILL SITE
}

\author{
O. N. AKOMAH AND G. O. ABU
}

(Received 4 December 2017; Revision Accepted 12 March 2018)

\begin{abstract}
The study was designed to evaluate the bacterial diversity of crude oil contaminated site. Sediments samples collected at different georeferenced sampling point; Nwata A, Nwata B, Nwata 3, Ochani and Eyeyaro in EjamahEbubu were analyzed for microbiological and biochemical qualities using the basic biological method. Our results show that the total aerobic heterotrophic bacteria (HUB) of the five sampling points range from $1.0 \times 10^{5}-1.7 \times 10^{6} \mathrm{cfu} / \mathrm{g}$. Total aerobic hydrocarbon utilizing bacteria (HUB) range from $1.0 \times 10^{4}-7.2 \times 10^{5} \mathrm{cfu} / \mathrm{g}$ while sulphate reducing bacteria (SRB) ranged between $2.2 \times 10^{4}-1.6 \times 10^{5} \mathrm{cell} / \mathrm{ml}$. Careful phenotypic and biochemical test revealed twenty oil degrader belonging to five genera; Bacilus, Citrobacter, Micrococcus, Enterobacter and Pseudomonas. The frequency of occurrence of the microbial isolate revealed Bacillus (40\%), Citrobacter, (25\%) Pseudomonas (15\%), Enterobacter and Micrococcus (10\%). This study indicates that the contaminated sediment samples contain a diverse population of oil degrading bacteria and the use of sediment-associated microorganism has the potential for bioremediation of crude oil contaminated sites.
\end{abstract}

KEYWORDS: Georeferenced, crude oil, diversity, Bacillus, sulphate reducing bacteria

\section{INTRODUCTION}

The Ecosystem is a self-supporting unit that is made up of a living part and a non living part. A component may function as biotic today but after a few months it may die and become abiotic (Kinako and AwiWaadu, 2000) because of the presence of contaminants. Oil pollution poses a serious threat to many terrestrial ecosystem. It reduces biodiversity and ecosystem productivity (Kinako, 1981; Kinako, 1988).

Despite more stringent environmental regulation, the risk of an oil spill affecting the ecosystem is still high because of extensive coastal oil production refining and transportation; also major oil spills are likely to increase in the coming years as oil industry strives to extract oil from increasing remote and difficult terrains. Future supplies will therefore be off-shore, deeper and harder and in the event of any mishap will be harder to respond to (lbekwe, 2011).

The effect of hydrocarbon contamination on microbial population in soils can vary considerably and depending on the type, amount and age of the contamination in unsaturated soil it will remain localized potentially, exerting pronounced effects on the immediate soil microbiota (Bossert and Bartha, 1984).

Ejamah-Ebubu is the famous "Ebubu spill" that occurred during the Nigeria civil war that ended in the 1970. The community is traversed by the shell petroleum development company (SPDC) pipeline. The pipe released unquantified amount of crude oil following rupture. The site was engulfed in fire leaving an area about 15ha of bitumen-like material. The adjourning stream, Ochani stream became impacted from the released crude oil, the stream traverses a distance of about $3 \mathrm{~km}$ and empties into the bonny rivers close to the Onne seaport near Port Harcourt. The stretch of Ochani stream is a swampy area, constituting an important wetland with different activities by the communities, such as fishing, recreation, farming and domestic uses.

It is a very costly approach to treat oil contaminated site by conventional methods such as the use of chemicals; this conventional methods can be replaced by microorganism or engineered microorganism which can detoxify the contaminants into lesser toxic compounds (Baker, 1999; Owens et al., 1999). The ability of microbes to degrade organic contaminants into harmless constituents has been explored as a means to biologically treat contaminated environment. Since, microorganisms that grow on oil contaminated soil are much capable of degrading oil than those which are found on non-contaminated soil. The present study was therefore undertaken with a view to isolate and characterized hydrocarbon utilizing microorganism from oil contaminated site of over 40 years.

\section{MATERIALS AND METHODS}

\section{Sample collection}

Sediment samples were collected by stratified sampling method from Ejamah-Ebubu oil spill site. Its choice was informed by the heavy crude oil it received from a

O. N. Akomah, University of Port Harcourt, School of Science laboratory Technology Microbiology Technology option PMB 5323, Choba, Port Harcourt, Rivers State, Nigeria.

G. O. Abu, University of Port Harcourt, Faculty of Science, Department of Microbiology, PMB 5323, Choba, Port Harcourt, Rivers State, Nigeria. 
damaged Trans Niger pipeline. Using a manual sediment grab the sample was collected from $20-40 \mathrm{~cm}$ beneath the surface and were transferred into sterile plastic containers.

\section{Enumeration of Total Aerobic Heterotrophic Bacteria (THB)}

One gram of wet sediment sample was introduced into 9 $\mathrm{ml}$ of sterile physiological saline. This was shaken for even distribution of the sample. The resultant $10^{-1}$ dilution was further diluted to $10^{-5}$. Then $0.1 \mathrm{ml}$ of diluted sample was transferred to sterile Petri-dish and $10 \mathrm{ml}$ of molten nutrient agar medium was added, the medium and inoculum were combined by to and fro shaking and circular movement lasting for 10 seconds. The plates (in duplicates) were allowed to solidify and later incubated at room temperature $\left(28-30^{\circ} \mathrm{C}\right)$ for 24 hours. The colonies that develop on the plates were counted and expressed as colony forming unit per gram (cfu/g). Colonies were isolated and purified by repeated streaking using the medium and incubation conditions of the original isolation. The isolate were stored on agar slants at $4^{\circ} \mathrm{C}$ before characterization.

\section{Enumeration of Aerobic, Hydrocarbon Utilizing Bacteria (HUB)}

The mineral salts composition of Okpokwasili and Okorie (1988) solidified with agar were used to selectively isolate hydrocarbon utilizing bacteria using the vapour phase transfer method. About $0.1 \mathrm{ml}$ aliquots of sample was pour plated from $10^{-1}$ to $10^{-5}$ fold dilution using sterile molten mineral salt agar plates in duplicate. A $9 \mathrm{~cm}$ whatman No. 1 filter paper was placed inside each cover plate and flooded $10 \mathrm{ml}$ of fresh Bonny light crude oil (SPDC, Port Harcourt). The filter paper was first drained of excess crude before placing it in the lid. This served as sole source of carbon and energy; the plate were inverted on incubation with the agar over the crude soaked filter paper. The plates were incubated at room temperature $\left(28-30{ }^{\circ} \mathrm{C}\right)$ for 7 days, thereafter, the viable counts as hydrocarbon degrading bacteria in the sample were taken and colonies purified by streaking on fresh nutrient agar and later stored in slants at $4^{\circ} \mathrm{C}$ prior to characterization.

Estimation of Sulphate Reducing Bacteria (SRB) using the Most Probable Number (MPN) Method

The method of Abu (1992) was adapted. The Most probable number (MPN) procedure for enumeration of SRB was used. A total of 20 test-tubes containing $9 \mathrm{ml}$ Postgate medium were used for each sampling point. Each set of five test tubes were inoculated with $0.1 \mathrm{ml}$ of $10^{-3}, 10^{-4}, 10^{-5}$ dilution of test sample. A set of five tubes was used as control. The test-tubes were sealed with sterile cotton wool and incubated at $37^{\circ} \mathrm{C}$ for 21 days in an anaerobic jar. Black precipitates indicated the presence of sulphate reducing bacteria (SRB).

\section{Staining and Biochemical activities of purified cultures}

The morphological characteristic of isolates were identified by Gram's Stain and biochemical reactions following Bergey's manual as well as motility were tested. The biochemical reactions include oxidase, lactose, TSI, Slant, indose, MR, VP, Citrate and Catalyst.

\section{RESULT}

The aerobic heterotrophic bacterial count ranged between $4.0 \times 10^{4}-1.7 \times 10^{6} \mathrm{cfu} / \mathrm{g}$. The aerobic hydrocarbon utilizing bacterial count ranged between 1.0 $x 10^{4}-7.2 \times 10^{5} \mathrm{cfu} / \mathrm{g}$ for various sample points. The sulphate reducing bacterial counts ranged between $2.2 \mathrm{x}$ $10^{4} \quad-\quad 1.6 \quad x \quad 10^{5} \quad$ cells $/ \mathrm{ml}$.

Table 1: Aerobic Heterotropic Bacterial counts (cfu/g) obtained from various sampling points

\begin{tabular}{llllll}
\hline Days & Nwatu A & Nwatu B & Nwatu 3' & Egeyaro & Ochani \\
& & & & & \\
\hline $\mathbf{0}$ & $4.6 \times 10^{5}$ & $1.2 \times 10^{5}$ & $4.0 \times 10^{4}$ & TNTC & $5.4 \times 10^{5}$ \\
$\mathbf{1 4}$ & $3.0 \times 10^{5}$ & $2.0 \times 10^{5}$ & $1.7 \times 10^{6}$ & $1.9 \times 10^{5}$ & $2.0 \times 10^{5}$ \\
$\mathbf{2 8}$ & $1.4 \times 10^{5}$ & $1.6 \times 10^{5}$ & $1.7 \times 10^{6}$ & $2.0 \times 10^{5}$ & $5.3 \times 10^{4}$ \\
$\mathbf{4 2}$ & $8.0 \times 10^{5}$ & $1.0 \times 10^{5}$ & $3.0 \times 10^{5}$ & $1.2 \times 10^{6}$ & $2.0 \times 10^{5}$ \\
$\mathbf{5 6}$ & $8.0 \times 10^{5}$ & TFTC & $2.0 \times 10^{5}$ & TFTC & TFTC \\
\hline TFTC = Too few to count & TNTC = Too numerous to count & Values are given as mean of duplicates
\end{tabular}

Table 2: Hydrocarbon utilizing bacterial count cfu/g) obtained from various sampling points

\begin{tabular}{llllll}
\hline Days & Nwatu A & Nwatu B & Nwatu 3' & Egeyaro & Ochani \\
\hline 0 & $1.6 \times 10^{5}$ & $8.7 \times 10^{4}$ & $1.2 \times 10^{4}$ & $4.1 \times 10^{4}$ & TFTC \\
14 & $1.0 \times 10^{5}$ & $1.2 \times 10^{5}$ & $1.0 \times 10^{4}$ & $6.0 \times 10^{4}$ & TFTC \\
28 & $6.0 \times 10^{4}$ & $7.2 \times 10^{5}$ & $9.2 \times 10^{4}$ & $4.3 \times 10^{4}$ & $3.6 \times 10^{5}$ \\
42 & $6.0 \times 10^{5}$ & $1.8 \times 10^{5}$ & $3.2 \times 10^{4}$ & $4.4 \times 10^{4}$ & $6.0 \times 10^{4}$ \\
56 & $6.0 \times 10^{5}$ & TFTC & TFTC & TFTC & TFTC \\
\hline \multicolumn{5}{r}{} \\
\hline
\end{tabular}


Table 3: Sulphate Reducing Bacterial count (cells/ml) obtained from various sampling points

\begin{tabular}{llllll}
\hline Days & Nwatu A & Nwatu B & Nwatu 3' & Egeyaro & Ochani \\
\hline $\mathbf{0}$ & $5.5 \times 10^{4}$ & $3.4 \times 10^{4}$ & $2.2 \times 10^{4}$ & $3.4 \times 10^{4}$ & $5.5 \times 10^{4}$ \\
$\mathbf{1 4}$ & $9.2 \times 10^{4}$ & $5.5 \times 10^{4}$ & $3.4 \times 10^{4}$ & $3.4 \times 10^{4}$ & $5.5 \times 10^{4}$ \\
$\mathbf{2 8}$ & $9.2 \times 10^{4}$ & $5.5 \times 10^{4}$ & $5.5 \times 10^{4}$ & $9.2 \times 10^{4}$ & $9.2 \times 10^{4}$ \\
$\mathbf{4 2}$ & $1.6 \times 10^{5}$ & $5.5 \times 10^{4}$ & $9.2 \times 10^{4}$ & $9.2 \times 10^{4}$ & $9.2 \times 10^{4}$ \\
$\mathbf{5 6}$ & $1.6 \times 10^{5}$ & $1.6 \times 10^{5}$ & $9.2 \times 10^{4}$ & $9.2 \times 10^{4}$ & $1.6 \times 10^{5}$ \\
\hline
\end{tabular}

Values are given as mean of duplicates samples

Table 4: Biochemical Characteristics of Hydrocarbon Utilizing Bacteria

\begin{tabular}{|c|c|c|c|c|c|c|c|c|c|c|c|c|c|c|c|}
\hline 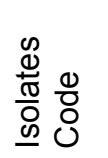 & 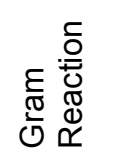 & $\begin{array}{l}0 \\
0 \\
\frac{0}{0} \\
\frac{0}{x} \\
0 \\
0\end{array}$ & 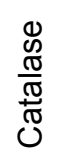 & 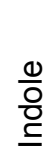 & 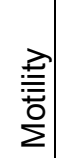 & $\stackrel{\Upsilon}{\Sigma}$ & $\stackrel{n}{>}$ & $\begin{array}{l}\frac{\vec{C}}{\omega} \\
\frac{\pi}{\omega} \\
\mapsto\end{array}$ & $\begin{array}{l}\overline{\mathbb{D}} \\
\bar{D} \\
\bar{\sigma} \\
\bar{\mapsto}\end{array}$ & 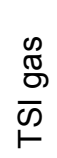 & $\begin{array}{l}\infty \\
\frac{N}{I} \\
\stackrel{D}{\vdash}\end{array}$ & $\begin{array}{l}0 \\
0 \\
0 \\
0 \\
\\
1\end{array}$ & 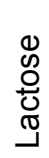 & 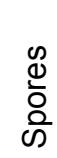 & Probable Isolate \\
\hline HUB1 & + Rod & - & + & - & + & - & + & $B$ & $B$ & - & - & + & - & + & Bacillus sp \\
\hline HUB2 & + Cocci & - & + & - & + & + & - & $B$ & $\mathrm{~A}$ & + & + & + & + & - & Citrobacter sp \\
\hline HUB3 & -Rod & + & + & - & & - & - & $A$ & $A$ & - & - & + & + & - & Pseudomonas sp \\
\hline HUB4 & + Cocci & - & + & - & + & - & + & A & A & + & - & + & + & - & Entrobacter sp \\
\hline HUB5 & + Cocci & + & + & - & + & + & + & $A$ & $\mathrm{~B}$ & + & + & + & + & - & Micrococcus sp \\
\hline
\end{tabular}

KEY: MR = Methyl red; VP = Vogues-proskaves; TSI = Triple sugar Iron Test; $A$ = Acid; $B=$ Alkaline(base)

HUB 1-5 = Hydrocarbon utilizing bacteria

\section{DISCUSSION}

Soil sample from Ejamah-Ebubu oil spill site contain an array of microorganisms. The high level of aerobic hydrocarbon utilizing bacteria at day 0 is a reflection of the degree of oil contamination owing to the fact that in an unpolluted environment the oil degraders would generally constitute less than $0.1 \%$ of the total heterotrophic population (Atlas, 1981, Osburne et al., 2000).

The hydrocarbon utilizing bacterial genera isolated from the oil contaminated soil were Bacillus (40\%), Citrobacter (25\%), Pseudomonous (15\%), Enterobacter (10\%) and Micrococus (10\%) with Bacillus sp having the highest percentage. Similar hydrocarbon utilizing bacteria were isolated by others researchers (Okpokwasili and Okorie, 1988; Chikere, and Okpokwasili, 2004; Charusheela and Modi, 2012). It has also been observed that some microorganisms are more abundant in areas of high concentration of hydrocarbons. These microorganisms are actively oxiding the hydrocarbons and this is considered as another source of carbon for use in the ecosystem.

The enumeration and isolation of sulphate reducing bacteria (SRB) has its inherent difficulties; agar poisoning, requiring specific condition and nutrient to grow, slow growth rate, etc. The most probable method was used for enumerating the SRB which recorded a high concentration at day 0 (table 3 ). The SRB were Grams negative rods with central spores.

\section{CONCLUSION}

Microbial degradation is the most significant natural mechanism for removal of hydrocarbon pollutants from the environment. Bacteria can be use to detoxify pollutants owing to their metabolic capabilities. The viable count procedure for isolating microorganisms using standard microbiological laboratory methods are inherently biased, as more species are unable to grow under a particular set of condition (Atlas, 1981, Osburne et al., 2000). Identification of the Sulphate reducing bacteria to the species level is necessary since SRB have been implicated in lot of industry damage nonetheless SRB also have their uses; in remediation of oil spill site under anoxic condition (Ghazi et al., 2011). Hence, for direct detection of genes responsible for degradation of hydrocarbon pollutants metagenomics should be employed.

\section{REFERENCES}

Atlas, R. M., 1981. Microbial degradation of Petroleum hydrocarbon; An Environmental Perspective. Microbial Rev., 45: 180-207.

Abu, G. O., 1992. Biotechnological, physiological and physiochemical strategy in monitoring and control of biocorrosion due to sulphate reducing bacteria (SRB) activities in petroleum producing systems. NICA/ICON 6: 47-52.

Baker, J. M., 1999. Ecological effectiveness of oil spill countermeasure: how clean is clean? Pure Appl. Chem., 71: 135-151.

Bossert, I and Bartha, R., 1984. The fate of Petroleum in Soil Ecosystem. In Atlas, R.M (Ed) Petroleum Microbiology. MacMillan, NY.

Charusheela, A and Modi, H. A., 2012. Study of Bacterial Diversity of Crude Oil Degrading Bacteria Isolated from Crude Oil Contaminated Sites. Life sciences Leaflets 6: 13-23.

Chikere, B. O and Okpokwasili, G. C., 2004. Frequency Occurrence of Microorganisms of a 
Petrochemical effluent outfall site. J. Trop. Biosci. , 4:12-18.

Ghazy, E. A., Mahmoud, M. G., Asker, M. S., Mahmoud, M. N., Abo Elsoud M. M. and Abdel Samie, M. E., 2011. Cultivation and detection of sulfate reducing bacteria (SRB) in sea water. Journal of American Science 7: 604-608.

Ibekwe, C., 2011. Ogoniland when will remediation work begin? Nigeria's Oil and Gas , 08.

Kinako, P. D. S., 1981. Short term effect of pollution on species numbers and productivity of a simple terestrial ecosystem; Environmental pollution, $26 ; 7-91$.

Kinako, P. D. S., 1988. Fundamental of quantitative and applied Plant Ecology. BELK Publishers, Nigeria.

Kinako, P. D. S and Awi-Waadu, G. D. B., 2000. General Ecology: A state of the Art Compendium of Ecology. BELK Publishers Nigeria.

Okpokwasili, G. C and Okorie, B. B., 1988. Biodeterioration Potential of Microorganisms isolated from Car Engine Lubricating oil. Tribology International 21:215 - 220.
Osburne, M. S., Grossman, T. H., August, P. R and MacNeil, I. A., 2000. Tapping into Microbiol Diversity for Natural Products Drug Discovery. America Society for Microbiology News $66: 411$ - 417.

Owens, E. H., Scienkiewiez, A. M and Sergy, G. A., 1999. Evaluation of shoreline cleaning versus natural recovery: the metula spill and the Komi operations, Proceeding of 999 international oil spill conference. American Petroluem institute, Washington, DC. 